\title{
The effect of educative interventions on the pressure ulcer prevention knowledge of nursing professionals*
}

\author{
Efeito de intervenções educativas no conhecimento dos profissionais de enfemagem sobre prevenção de \\ úlceras pressão
} Efectos de intervenciones educativas en el conocimiento de profesionales de enfermería sobre
prevención de úlceras por decúbito

\author{
Luciana Magnani Fernandes ${ }^{1}$, Maria Helena Larcher Caliri², Vanderlei José \\ Haas $^{3}$
}

\begin{abstract}
Objective: The aim was to evaluate the effect of the educative interventions on nursing staff knowledge about pressure ulcer prevention in Intensive Care Centers (ICC). It is a descriptive-comparative study. Methods: Data were collected from nursing team members before and after educative interventions using a knowledge test with true-false questions related to pressure ulcer prevention and description as a research instrument. Results: Seven registered nurses participated in the pre-intervention phase only and obtained $86.4 \%$ of correct answers. The nursing assistants and technicians $(n=25)$ obtained $74.3 \%$ of correct answers in the pre-intervention phase and $81.2 \%(n=36)$ in the post-intervention phase, showing improvement in the results after the intervention for this group. Conclusion: Even though the strategies used were not totally effective, as in some questions the rate of correct answers was below $70 \%$. New interventions might be used to obtain greater staff adhesion and to improve their knowledge about the issue.
\end{abstract}

Keywords: Pressure ulcer/prevention \& control; Intensive care; Knowledge

\section{RESUMO}

Objetivo: Avaliar o efeito de intervenções educativas, no nível de conhecimento dos membros da equipe de enfermagem sobre a prevenção de úlceras por pressão em um Centro de Terapia Intensiva. Métodos: Trata-se de um estudo descritivo comparativo. Os dados foram coletados antes e após a intervenção educativa, utilizando teste de conhecimento com afirmações verdadeiras ou falsas sobre medidas de prevenção e descrição da úlcera. Resultados: Sete enfermeiros participaram somente da fase pré-intervenção e obtiveram $86,4 \%$ de acertos no total de questões. Os auxiliares e técnicos de enfermagem na fase pré-intervenção ( $\mathrm{n}=25)$ obtiveram $74,3 \%$ de acertos e na fase pósintervenção $(\mathrm{n}=36)$ apresentaram melhora com $81,2 \%$ de acertos. Conclusão: As estratégias utilizadas não foram totalmente eficazes, pois em algumas questões os acertos pós-intervenção foram abaixo de $70 \%$. Novas intervenções precisam ser realizadas para obter maior adesão dos profissionais ao programa educativo e melhorar o conhecimento sobre o tema.

Descritores: Úlcera de pressão/prevenção \& controle; Cuidados intensivos; Conhecimento

\section{RESUMEN}

Objetivo: Evaluar el efecto de las intervenciones educativas, en el nivel de conocimiento de los miembros del equipo de enfermería respecto a la prevención de úlceras por decúbito en un Centro de Cuidados Intensivos. Métodos: Se trata de un estudio descriptivo comparativo. Los datos fueron recolectados antes y después de la intervención educativa, utilizando un test de conocimiento con afirmaciones verdaderas o falsas sobre medidas de prevención y descripción de la úlcera. Resultados: Sólo siete enfermeros participaron de la fase de pre-intervención y obtuvieron el $86,4 \%$ de aciertos en el total de preguntas. Los auxiliares y técnicos de enfermería en la fase de pre-intervención ( $\mathrm{n}=25$ ) obtuvieron el $74,3 \%$ de aciertos y en la fase de post-intervención ( $\mathrm{n}=36)$ presentaron mejoría con el 81,2\% de aciertos. Conclusión: Las estrategias utilizadas no fueron totalmente eficaces, pues en algunas preguntas los aciertos de post-intervención estuvieron debajo del $70 \%$. Es preciso realizar nuevas intervenciones para obtener una mayor adhesión de los profesionales al programa educativo y mejorar el conocimiento sobre el tema.

Descritores: Úlcera por decúbito/prevención \& control; Cuidados intensivos; Conocimiento

\footnotetext{
* Work extracted from a Doctorate Degree Dissertation: The Effects of Educative Interventions on the Knowledge and Practices of Nursing Professionals and the Incidence of Pressure Ulcers in an Intensive Therapy Center.

${ }^{1}$ Ph.D., Professor of the Nursing Undergraduate Course at Universidade Estadual do Oeste do Paraná - UNIOESTE - Cascavel, (PR), Brazil.

2 Associate Professor, Member of of Department of General and Specialized Nursing at Escola de Enfermagem de Ribeirão Preto at Universidade de São Paulo- USP - Ribeirão Preto, (SP), Brazil.

${ }^{3}$ Ph.D. Grant from Prodoc/Capes at the Department of General and Specialized Nursing of the Escola de Enfermagem de Ribeirão Preto at Universidade de São Paulo - USP - Ribeirão Preto, (SP), Brazill.
} 


\section{INTRODUCTION}

Pressure ulcers (PU) represent a significant threat to individuals with mobility or sensory perception impairment, with immobility as a risk factor of higher importance in hospitalized patients ${ }^{(1)}$. PU are considered a severe clinical problem in institutionalized patients or care in households worldwide and efforts have been made for evidence-based prevention measures to be used aiming at reducing the occurrences. PU increase morbidity and mortality, the time and hospitalization cost, diminishing the patients' life quality and are often considered iatrogenic ${ }^{(2)}$.

Patients in Intensive Care Units have greater risks of developing PU. They are often sedated or with alteration in the level of consciousness and remain in bed for a prolonged time, maintained under ventilatory support, with the use of vasoactive drugs and show hemodynamic instability ${ }^{(3)}$.

Since the nineties, pressure ulcers have been considered to be a negative care outcome and adopted as one of the indicators of nursing assistance quality by North-American institutions ${ }^{(3)}$, with directed efforts to reduce its incidence by means of prevention $\operatorname{programs}^{(4)}$.

The care individualization through nursing care systematization and the use of recommendations for the evidence-based clinical practices may improve the care quality and provide benefits for the patients ${ }^{(5)}$. However, such challenge is focused on how to perform the transport of evidences to the clinical practice and favor its use by professionals ${ }^{(5)}$. The spread of knowledge, in a given setting, occurs as a decision process by innovation, which consists of five stages: knowledge, persuasion, decision, implementation and confirmation $^{(6)}$. These aspects are used by researchers as study variables in order to identify in what stage of innovation the individual is, and to use strategies that favor process advancement. Several strategies for knowledge spread may be used, aiming at obtaining better results in the adoption process of an innovation, with emphasis on educational programs, lectures, readings, conferences, use of written material and protocols for evidence-based practices, and availability of specialists in the area $^{(7)}$.

With the purpose of contributing to the advance of knowledge in this area, the study was conducted by nursing team members of an Intensive Therapy Center of a tertiary university hospital in the countryside of Sao Paulo. The study aimed at investigating the effect of educative intervention, made up of several strategies, recommended in literature, on the level of nursing professional knowledge regarding recommended measures to prevent PU.

\section{METHODS}

This is a quantitative study with descriptivecomparative orientation, which was approved by the Institutional Committee of Ethics in Research of the institution where the study was carried out. The body of nursing team professionals was composed of 11 nurses, 10 technicians and 29 nursing assistants distributed in several shifts. All of them were invited to participate and the informed consent form was obtained.

Data collection in the study regarding the dependent variable (knowledge of the professionals) was performed in January and February 2005, before and after the educative intervention, using an instrument.

The educative intervention (independent variable) aimed at presenting the aspects involving the PU formation and prevention ${ }^{(8)}$. It was carried out for two months by using different strategies such as expositive classes with dialogs, group discussion about the current practice, spread of knowledge by means of posters that were fixed in different places in the unit, and providing the subjects with leaflets and a written guide. For 15 days, the researcher remained in the field to give the professionals the opportunity to get further information that they regarded as necessary.

The data collection instrument was composed of questions referring to demographic data and knowledge test, developed by American authors and validated in a previous study carried out in Brazil ${ }^{(9)}$. The test is composed of 41 true or false statements whose contents come from North-American guideline recommen-dations for the evidence-based practice to predict and prevent PU with text adaptation for the context of assistance of the critical patient. Of the 41 knowledge test items, 6 refer to ulcer classification/ onset (items 1, 6, 9, 20, 33 and 38); 2 refer to wound characteristics (items 31 and 32 ) and the others to prevention measures.

The subjects were asked to answer the test, with option for each item, True (T) when they agreed with the recommendation, False (F) when they disagreed and Do not know (DK) when they did not know the answer. For each correct answer, a point. The points corresponded to $\mathrm{V}$ questions answered as true and $\mathrm{F}$ questions answered as false. There were not points for wrong answers or those answered DK. The total score of the knowledge test corresponded to the sum of all the correct answers and the partial score corresponded to the sum of answers of each of the three parts (onset, would characteristics and prevention). For an item to be considered as known by the professionals, 90\% should answer correctly.

The instrument was distributed to the subjects who 
accepted to participate in the study and they answered it individually during working hours and gave it back to researcher immediately. In order to guarantee the participant privacy, there was no information collection that could reveal their identities.

The collected data were entered in an Excel spreadsheet for the analysis of the SPSS software (Statistical Package for Social Science). The analysis considered the scores of the two professional groups and not the isolated scores of each subject.

\section{RESULTS}

Of the 50 nursing team members, all of them had had contact with the strategies of educative intervention performed in the field. However, only $30 \%$ of the subject participated in the expositive classes and group discussions. Thirty-two professionals completed the instrument in the pre-intervention phase, among them there were 17 nursing assistants (53\%), 8 nursing technicians $(25 \%)$ and 7 nurses $(22 \%)$. In the postintervention phase, 36 participated, of which 27 nursing assistants $(75 \%)$ and 9 nursing technicians (25\%).
The nurses answered the instrument only in the preintervention phase. They had between 2 to 12 years of higher education experience (mean of $6.8, \mathrm{SD}=3.67$ ) and from 3 to 8 years of practice in ICC (mean of 4.7, $\mathrm{SD}=3.7)$.

The technicians/assistants who answered the instrument before intervention had between 1 to 23 years of experience (mean of $10.2, \mathrm{SD}=3.52$ ) and between 1 to 19 years of practice in ICC (mean of 7.39, SD = 3.52). The technicians/assistants who participated in the post-intervention phase had between 1 to 25 years of experience (mean of 9.7 years, SD = 3.58 ) and between 1 to 25 years in ICC (mean of 6.3 , $\mathrm{SD}=3.75$ )

Considering the test global results (41 items), the nurses obtained $86.4 \%$ of correct answer ( $\mathrm{SD}=4.6)$. The assistants and technicians obtained $74.3 \%$ of correct answers $(\mathrm{SD}=14.8)$ in the pre-intervention phase and $81.2 \%(\mathrm{SD}=12.7)$ in the post-intervention phase, demonstrating that for this group of professionals, the intervention helped improve the test results. The results obtained in each part of the knowledge test for nurses (pre-intervention) and assistants and technicians (pre and

Table 1 - Rates of correct answers of nurses, assistants and nursing technicians, in the test questions regarding PU onset, in the educative pre- and post-intervention.

\begin{tabular}{|c|c|c|c|c|c|c|c|}
\hline \multirow[t]{2}{*}{$\mathbf{N}$} & \multirow[t]{2}{*}{ Onset questions } & \multicolumn{2}{|c|}{$\begin{array}{l}\text { Nurses } \\
(n=7)\end{array}$} & \multicolumn{2}{|c|}{$\begin{array}{c}\text { Assistants and } \\
\text { technicians } \\
\text { Pre }(n=25)\end{array}$} & \multicolumn{2}{|c|}{$\begin{array}{c}\text { Assistants } \\
\text { and } \\
\text { technicians } \\
\text { Post }(n=36)\end{array}$} \\
\hline & & $\mathrm{n}$ & $\%$ & $\mathrm{n}$ & $\%$ & $\mathrm{~N}$ & $\%$ \\
\hline 9 & $\begin{array}{l}\text { Pressure ulcers in stage IV show total skin loss with intense } \\
\text { destruction and tissue necrosis or muscles, bones or supporting } \\
\text { structures damage. (T) }\end{array}$ & 7 & 100.0 & 22 & 88.0 & 34 & 94.4 \\
\hline 3 & A blister in the calcaneus should be a reason for concern $(\mathrm{F})$ & 7 & 100.0 & 20 & 80.0 & 27 & 75.0 \\
\hline 1 & $\begin{array}{l}\text { Stage I of pressure ulcer is defined as an erythema that does not } \\
\text { whiten }(T)\end{array}$ & 7 & 100.0 & 18 & 72.0 & 34 & 94.4 \\
\hline 38 & $\begin{array}{l}\text { The pressure ulcers in stage II may be extremely painful because } \\
\text { of the exposure of the nervous ends (T) }\end{array}$ & 2 & 28.6 & 17 & 68.0 & 27 & 75.0 \\
\hline 20 & Pressure ulcers in stage II show skin loss in the total thickness $(F)$ & 7 & 100.0 & 15 & 60.0 & 18 & 50.0 \\
\hline 6 & $\begin{array}{l}\text { A pressure ulcer in stage III is a partial skin loss involving } \\
\text { epidermis }(F)\end{array}$ & 5 & 71.0 & 4 & 16.0 & 16 & 44.4 \\
\hline
\end{tabular}

Table 2 - Rates of correct answers of nurses, assistants and nursing technicians, in the test questions regarding evaluation, in the educative pre- and post-intervention.

\begin{tabular}{|c|c|c|c|c|c|c|c|}
\hline \multirow[t]{2}{*}{ No } & \multirow[t]{2}{*}{ Evaluation questions } & \multicolumn{2}{|c|}{$\begin{array}{c}\text { Nurses } \\
\text { Pre }(n=7)\end{array}$} & \multicolumn{2}{|c|}{$\begin{array}{c}\text { Assistants and } \\
\text { Technicians } \\
\text { Pre }(n=25)\end{array}$} & \multicolumn{2}{|c|}{$\begin{array}{c}\text { Assistants and } \\
\text { Technicians } \\
\text { Post }(\mathrm{n}=36) \\
\end{array}$} \\
\hline & & n & $\%$ & $\mathbf{n}$ & $\%$ & $\mathbf{N}$ & $\%$ \\
\hline 31 & Pressure ulcers are sterile wounds $(\mathrm{F})$ & 5 & 71.0 & 19 & 76.0 & 24 & 66.7 \\
\hline 32 & $\begin{array}{l}\text { A pressure ulcer scar may be damaged faster than the whole } \\
\text { skin }(T)\end{array}$ & 5 & 71.0 & 20 & 80.0 & 31 & 86.1 \\
\hline
\end{tabular}


Table 3 - Rates of correct answers of nurses, assistants and nursing technicians, in the test questions regarding prevention, in the educative pre- and post-intervention.

\begin{tabular}{|c|c|c|c|c|c|c|c|}
\hline \multirow[t]{2}{*}{$\mathbf{N}$} & \multirow[t]{2}{*}{ Prevention Questions } & \multicolumn{2}{|c|}{$\begin{array}{l}\text { Nurses } \\
\operatorname{Pre}(n=7)\end{array}$} & \multicolumn{2}{|c|}{$\begin{array}{l}\text { Assistants } \\
\quad \text { and } \\
\text { Technicians } \\
\text { Pre }(n=25)\end{array}$} & \multicolumn{2}{|c|}{$\begin{array}{l}\text { Assistants } \\
\text { and } \\
\text { Technicians } \\
\text { Post }(\mathrm{n}=36)\end{array}$} \\
\hline & & $\mathrm{n}$ & $\%$ & $\mathbf{n}$ & $\%$ & $\mathbf{N}$ & $\%$ \\
\hline 2 & $\begin{array}{l}\text { Risks of developing pressure ulcer: mobility; incontinence; suitable } \\
\text { nutrition and alteration in the consciousness level }(\mathrm{T})\end{array}$ & 7 & 100.0 & 23 & 92.0 & 31 & 86.1 \\
\hline 3 & $\begin{array}{l}\text { All the individuals at pressure ulcer risk should have a systematic skin } \\
\text { inspection at least once a week }(\mathrm{F})\end{array}$ & 5 & 71.4 & 13 & 52.0 & 23 & 63.9 \\
\hline 4 & $\begin{array}{l}\text { Hot water and soap may dry the skin and increase the risk of pressure } \\
\text { ulcer }(T)\end{array}$ & 4 & 57.1 & 18 & 72.0 & 31 & 80.1 \\
\hline 5 & $\begin{array}{l}\text { It is important to massage the osseous prominences if they are reddish } \\
\text { (F) }\end{array}$ & 7 & 100.0 & 11 & 44.0 & 28 & 77.8 \\
\hline 7 & $\begin{array}{l}\text { Everybody, at admission, should be evaluated regarding the risk of } \\
\text { developing pressure ulcer }(\mathrm{T})\end{array}$ & 7 & 100.0 & 24 & 96.0 & 34 & 94.4 \\
\hline 8 & $\begin{array}{l}\text { Starch, creams, transparent dressings (ig Tegaderm or Opsite) and } \\
\text { hydrocoloid dressings (ig Duoderm) do not protect against the friction } \\
\text { effects. (T) }\end{array}$ & 5 & 71.4 & 15 & 60.0 & 21 & 58.3 \\
\hline 10 & $\begin{array}{l}\text { A diet intake suitable to the patient protein-calorie needs should be } \\
\text { maintained during the disease }(T)\end{array}$ & 7 & 100.0 & 24 & 96.0 & 33 & 91.7 \\
\hline 11 & Bedridden people should be repositioned every 3 hours $(\mathrm{F})$ & 7 & 100.0 & 13 & 52.0 & 28 & 77.8 \\
\hline 12 & A timetable for decubitus change should be written for each patient $(\mathrm{T})$ & 6 & 85.7 & 19 & 76.0 & 33 & 91.7 \\
\hline 13 & Protector such as water gloves soothe the calcaneus pressure $(\mathrm{F})$ & 6 & 85.7 & 14 & 56.0 & 27 & 75.0 \\
\hline 14 & $\begin{array}{l}\text { Donut-shaped or ring-shaped cushions help with the pressure ulcer } \\
\text { prevention }(\mathrm{F})\end{array}$ & 6 & 85.7 & 14 & 56.0 & 29 & 80.6 \\
\hline 15 & Laterally, the person should be in a 30 degree angle with the bed (T) & 5 & 71.4 & 18 & 72.0 & 32 & 88.9 \\
\hline 16 & $\begin{array}{l}\text { The bed should be raised and maintained in a low level of elevation } \\
\text { (not higher than a } 30 \text { degree angle) in compliance with the clinical } \\
\text { conditions and medical recommendations (T) }\end{array}$ & 5 & 71.4 & 14 & 56.0 & 31 & 86.1 \\
\hline 17 & $\begin{array}{l}\text { A person who cannot move should be repositioned while sitting in bed. } \\
\text { every } 2 \text { hours }(\mathrm{F})\end{array}$ & 2 & 28.6 & 3 & 12.0 & 12 & 33.3 \\
\hline 18 & $\begin{array}{l}\text { The people who can learn should be oriented to change their weight } \\
\text { every } 15 \text { minutes while sitting in the chair }(T)\end{array}$ & 6 & 85.7 & 18 & 75.0 & 31 & 86.1 \\
\hline 19 & $\begin{array}{l}\text { The people who remain in the chair should use a cushion for the chair } \\
\text { protection }(T)\end{array}$ & 5 & 71.4 & 22 & 88.0 & 27 & 75.0 \\
\hline 21 & The skin should remain clean and dry $(\mathrm{T})$ & 6 & 85.7 & 20 & 80.0 & 33 & 91.7 \\
\hline 22 & $\begin{array}{l}\text { Prevention measures are not required to prevent new lesions when the } \\
\text { patient already has pressure ulcer }(F)\end{array}$ & 7 & 100.0 & 21 & 84.0 & 32 & 88.9 \\
\hline 23 & $\begin{array}{l}\text { Mobile sheets or bedding should be used to transfer or move patients } \\
\text { (T) }\end{array}$ & 6 & 85.7 & 22 & 88.0 & 32 & 88.9 \\
\hline 24 & $\begin{array}{l}\text { Mobilization and transference of totally dependent patients should be } \\
\text { performed by two or more people }(\mathrm{T})\end{array}$ & 7 & 100.0 & 24 & 96.0 & 34 & 94.4 \\
\hline 25 & $\begin{array}{l}\text { Rehabilitation measures should be instituted if the general status of the } \\
\text { patient permits }(T)\end{array}$ & 6 & 85.7 & 21 & 84.0 & 30 & 83.3 \\
\hline 26 & $\begin{array}{l}\text { Every patient admitted in the Intensive Therapy Unit should be } \\
\text { subjected to a risk evaluation of developing pressure ulcer }(\mathrm{T})\end{array}$ & 7 & 100.0 & 23 & 92.0 & 35 & 97.2 \\
\hline 27 & $\begin{array}{l}\text { Patients and relatives should be oriented about the causes and risk } \\
\text { factors of development of pressure ulcer }(\mathrm{T})\end{array}$ & 7 & 100.0 & 23 & 92.0 & 35 & 97.2 \\
\hline 28 & The osseous prominences may be in touch $(\mathrm{F})$ & 7 & 100.0 & 24 & 96.0 & 33 & 91.7 \\
\hline 29 & $\begin{array}{l}\text { Every person evaluated as at risk of developing pressure ulcer should } \\
\text { be placed on a pressure reducing mattress (i.g water mattress }(T)\end{array}$ & 6 & 85.7 & 20 & 80.0 & 30 & 83.3 \\
\hline 30 & The skin exposed to humidity is more easily damaged $(\mathrm{T})$ & 7 & 100.0 & 23 & 92.0 & 33 & 91.7 \\
\hline 34 & A measure to reduce the calcaneus pressure is to elevate them $(\mathrm{T})$ & 6 & 85.7 & 21 & 84.0 & 32 & 88.9 \\
\hline 35 & $\begin{array}{l}\text { All the administered care to prevent and treat pressure ulcers should } \\
\text { not be documented }(\mathrm{F})\end{array}$ & 7 & 100.0 & 23 & 92.0 & 31 & 86.1 \\
\hline 36 & $\begin{array}{l}\text { Shear is the power that occurs when the skin adheres to a surface and } \\
\text { the body slides in the opposite direction }(\mathrm{T})\end{array}$ & 6 & 85.7 & 10 & 40.0 & 28 & 77.8 \\
\hline 37 & Friction may occur when the person is moved in bed $(\mathrm{T})$ & 7 & 100.0 & 22 & 88.0 & 32 & 88.9 \\
\hline 39 & $\begin{array}{l}\text { For people with incontinence, the cleaning of the skin should start the } \\
\text { moment it occurs and in the routine intervals }(\mathrm{T})\end{array}$ & 7 & 100.0 & 23 & 92.0 & 34 & 94.4 \\
\hline 40 & Educational programs may reduce the pressure ulcer incidence $(\mathrm{T})$ & 7 & 100.0 & 23 & 92.0 & 34 & 94.4 \\
\hline 41 & $\begin{array}{l}\text { Hospitalized patients need to be evaluated regarding the risk of } \\
\text { pressure ulcer only once }(\mathrm{F})\end{array}$ & 7 & 100.0 & 21 & 84.0 & 33 & 91.7 \\
\hline
\end{tabular}


post-intervention) are shown in Tables 1 and 3 .

The test results in the PU onset part are shown in Table 1.

The nurses answered correctly $100 \%$ of the four questions regarding ulcer onset (I, II and IV). However, in two questions, the rate of correct answers was low, with emphasis on the knowledge deficit in the item that refers to the justification of pain in pressure ulcers in stage II $(28.6 \%$ of correct answers).

In the pre-intervention phase, the assistants and nursing technicians showed low rates of correct answers (lower than $70 \%$ ) in 3 questions. The lowest correct answers result $(16 \%)$ was obtained in the question referring to the PU description in stage III. In the postintervention phase, in 4 questions, there was improvement in the rates of correct answers. However, in 2 questions, the rates obtained were lower than $70 \%$, demonstrating failure in knowledge.

In Table 2, the results are presented regarding the two evaluation questions.

The nurses obtained $71 \%$ of correct answers and the assistants and nursing technicians more than $76 \%$ in the pre-intervention phase. In question 31, in the postintervention phase, the rates of correct answers was lower than in the pre-test phase, indicating knowledge deficit even after intervention.

Concerning the 33 questions in test in the PU prevention part (Table 3), in 16 items, the nurses obtained $100 \%$ of correct answers and in 10, they obtained $85.7 \%$ of correct answers. The item with the highest rates of correct answers $(28.6 \%)$ was the statement that referred to the need of repositioning every 2 hours in wheelchair patients (who cannot move without help).

The assistants and nursing technicians did not obtain $100 \%$ of correct answers in any questions in any of the two moments, before $(76 \%)$ or after $(84.3 \%)$ the educative intervention. Nevertheless, in the preintervention phase, in 20 questions they obtained rates of correct answers between $80 \%$ and $96 \%$. Also, for this group, the item with the highest number of correct answers $(12 \%$ and $33.3 \%$, in the pre- and postintervention phases, respectively) referred to the need of repositioning every 2 hours in wheelchair patients. In the post-intervention phase, in 23 questions, the assistants and nursing technicians obtained more correct answers and in 25, the rates of correct answers were higher than $80 \%$, which evidences an increase in the correct answers after intervention.

\section{DISCUSSION}

The data presented show that the educative intervention produced positive outcomes in the global correct answer rates in the questionnaire about knowledge regarding PU preventive measures, its onset and evaluation. However, in some questions, the level of knowledge was below $70 \%$. This comparative evaluation could not be performed in relation to the nurses scores due to the fact that they did not participate in the post-intervention phase.

The knowledge of the prevention measures and pressure ulcer characteristics should become part of the knowledge list of all the nursing field professionals. The PU increased incidence in hospitalized patients and the cost for the health system urged governmental institutions and unions in several countries to formulate recommendations for the clinical practice ${ }^{(5)}$. The recommendations that include measures related to the identification of patients in risk and the handling of conditions that lead to the development of PU, but they also point out the importance of education in patients, formal or informal caregivers, and all the other members of the health team. There is also the need of researches that investigate strategies to cope with complex questions that involve the development of PU and how to transport evidences to the practice and gather the necessary resources to minimize the problem ${ }^{(5)}$.

The models of using evidence for clinical practice adopts ideas proposed by Rogers ${ }^{(6)}$ to disseminate innovations and point out that for each new knowledge that is used, there is the need of spreading it to the professionals involved in the practice, which will have to be persuaded when it comes to the need of changing their behaviors ${ }^{(4,10-11)}$. In this study, the nurses had less than 7 years of experience in average and the assistants/technicians, 10 years. These data may contribute to the explanation of the deficit in knowledge of there practitioners about certain PU prevention and identification aspects, which are more recent in this area such as the onset and the lesion characteristics.

In a study with 228 American nurses, in which the preliminary version of this instrument was used, the mean global correct answers was $33.7 \%$. The nurses who acknowledged recent access to pressure ulcer information, through lectures or papers had higher scores in the knowledge test. However, the differences in the level of knowledge are not associated with the educational background, age or nursing experience ${ }^{(9)}$.

In another study with 75 American nurses who worked in intensive care units, with the preliminary version of the instrument, in only 15 of the items, the professionals obtained $90 \%$ or more of correct answers. The authors concluded that there was deficit in the nurse knowledge and that there was the need of improvement in knowledge, considering that the goal of nursing is to provide competent nursing care $^{(12)}$. 
In Brazil, a study with 25 nurses of a general private hospital that also used the preliminary test, the mean global correct answers was $32.48 \%(\mathrm{SD}=4.7)$. In the prevention category the mean correct answers was $71.1 \%$. In the onset category, it was $67.2 \%$ and in the evaluation category, it was $80.6 \%$. The nurses who often looked for information with their peers or used the internet to access guidelines obtained better results in the test ${ }^{(13)}$.

The question of increase in the knowledge of professionals about pressure ulcer, due to participation in educational programs, certification courses, participation in lectures about the topic and searches on the internet was confirmed in a recent study with American nurses with different educational backgrounds using the same knowledge test of this study ${ }^{(14)}$. Curiously, the question with the lowest rate of correct answers by the American nurses was similar to those found in this study with nurses and assistant/nursing technicians regarding the repositioning time of the person sitting in a wheelchair, evidencing this is an aspect not understood by the professionals in both contexts.

The little participation of nurses and the lack of participation in the post-intervention phase did not allow the evaluation of the intervention effect for this group. Even though the research project was presented to the Nursing Direction of the institution and of the unit and its importance for the awareness of the service reality and for the performance of future changes, the professionals were not given several options to choose from. The literature points out that the institutional barriers are the most difficult to break and implement

\section{REFERENCES}

1. Lindgren M, Unosson M, Fredrikson M, Ek AC. Immobility - a major risk factor for development of pressure ulcers among adult hospitalized patients: a prospective study. Scand J Caring Sci. 2004; 18(1): 57-64.

2. Fernandes LM. Úlcera de pressão em pacientes críticos hospitalizados: uma revisão integrativa da literatura [dissertação]. Ribeirão Preto: Escola de Enfermagem de Ribeirão Preto da Universidade de São Paulo; 2000.

3. Fernandes LM, Caliri MHL. Úlcera de pressão em pacientes críticos hospitalizados: uma revisão integrativa da literatura. Rev Paul Enferm. 2000; 19(2): 25-31.

4. Graham K, Logan J. Using the Ottawa Model of Research use to implement a skin care program. J Nurs Care Qual. 2004; 19(1): 18-24; quiz 25-6.

5. Caliri MHL. A utilização da pesquisa na prática clínica de enfermagem: limites e possibilidades [tese ]. Ribeirão Preto: Escola de Enfermagem de Ribeirão Preto da Universidade de São Paulo; 2002.

6. Rogers EM. Diffusion of innovations. 5th ed. New York: Free Press; 2003.

7. Rabeh SAN, Caliri MHL. Úlcera de pressão: estratégias para divulgação do conhecimento na literatura de enfermagem. Rev Paul Enferm. 2003; 22(3): 307-14. the new ideas and innovations in the health organizations and that organizational infra-structure, philosophy and vision interfere in the adoption of innovations ${ }^{(5,10-11)}$.

\section{CONCLUSIONS}

Pressure ulcer, although it is a quality indicator (negative) of the health services, still is an underestimated problem by the professionals. It continues to often occur in ICC patients ${ }^{(15)}$, posing a scenery that shows the need of urgent measures to change this situation. Knowledge deficit, allied to the use of inappropriate practices by the professionals, contributes to the maintenance of this situation. Pressure ulcer prevention requires better understanding of the professionals about the aspects involving its development, as well as attitudes towards ethical care with the adoption of recommended practices, including the search of suitable resources. Several strategies may be used to improve the level of professional knowledge. However, it is necessary to identify the personal and institutional barriers that impair such goal.

The strategies used to ensure educative intervention performed in this study are important tools to spread recommendations for pressure ulcer prevention and may be used by teaching and assistance institutions, as. PU are negative indicators of the service quality. The knowledge test used in this research can also be used by researchers and professors working in this area, leading to the comparisons of results obtained in different populations.
8. Wound, Ostomy, and Continence Nurses Society (WOCN). Guideline for prevention and management of pressure ulcers. Glenview (IL): Wound, Ostomy, and Continence Nurses Society (WOCN); 2003. 52 p.

9. Pieper B, Mott M. Nurses' knowledge of pressure ulcer prevention, staging, and description. Adv Wound Care. 1995; 8(3): 34, 38, 40 passim.

10. Registered Nurses Association of Ontario (RNAO). Risk assessment and prevention of pressure ulcers. Toronto (ON): Registered Nurses Association of Ontario (RNAO); 2002.56 p.

11. Royal College of Nursing (RCN). Pressure ulcer risk assessment and prevention. London: RCN; 2002.

12. Pieper B, Mattern JC. Critical care nurses' knowledge of pressure ulcer prevention, staging and description. Ostomy Wound Manage. 1997; 43(2): 22-6, 28, 30-1.

13. Rangel EML, Caliri MHL. Conhecimento de enfermeiros de um hospital geral sobre a prevenção e avaliação da úlcera de pressão. Rev Paul Enferm. 2004; 23(2):123-9.

14. Zulkowski K, Ayello EA, Wexler S. Certification and education: do they affect pressure ulcer knowledge in nursing? Adv Skin Wound Care. 2007; 20(1): 34-8.

15. Fernandes LM. Efeitos de intervenções educativas no 
conhecimento e práticas de profissionais de enfermagem e na incidência de úlcera de pressão em centro de terapia intensiva [tese]. Ribeirão Preto: Escola de Enfermagem de Ribeirão Preto da Universidade de São Paulo; 2006. 